\title{
Performance of Garden Pea Genotypes in Eastern Hills of Nepal
}

\author{
Krishna Poudel $^{@}$, Ajaya Karkee, Manoj Kumar Shah and Sujan Karki
}

Agricultural Research Station, Pakhribas, Dhankuta, @ : <krishnapoudel08@gmail.com>, (D http://orcid.org/0000-0001-8351-9665; AK <ajayakarkee@gmail.comemail>; MKS <mksanghaesha@gmail.comemail>; SK <ksujan165@gmail.comemail>

Received November 2016, Revised August 2016, Accepted January 2017, Published May 2017

Scientific Editors: Umesh Acharya, Bal K. Joshi

Copyright (C2017 NARC. Permits unrestricted use, distribution, and reproduction in any medium, provided the original work is properly cited.

\begin{abstract}
Garden pea (Pisum sativum L) is an important winter legume used as fresh vegetables and other drier food products. Despite of its importance as cash crop in many parts of Nepal, much study on various aspects for enhancing production and productivity has yet to be done. Therefore, to evaluate the production performance different genotypes of garden pea in eastern hills agro-ecological conditions present experiments were carried out consecutively for two years (2015 and 2016) at Agricultural Research Station, Pakhribas. The experiment comprised of 11 different genotypes of garden pea including a check variety Arkel. The production performance was evaluated in a completely randomized block design with three replications. The seeds were sown at $50 \times 10 \mathrm{~cm}$ spacing during first week of October for two years. The result showed that DGP-05 genotype had earliest 104 days after sowing. The DGP-08 genotype showed 13 which were the maximum numbers of pods per plant (13), while DGP-01 showed 8 numbers of seeds as the maximum per pod. The DGP-03 genotype had the longest pod of $9.78 \mathrm{~cm}$ among others. The highest fresh pod yield of $18.14 \mathrm{t} / \mathrm{ha}$ was achieved from genotype DGP-09 followed by Arkel with (16.32 t/ha).
\end{abstract}

Keywords: Arkel, garden pea, genotypes, pod, response

सारांश

हरियो केराउ एक महत्वपूर्ण पोषिलो तरकारी मध्ये पर्द छ, तथापि केहि प्रारम्भिक अभिलेख बाहेक आबश्यकता अनुसारको परीक्षणहरु हुने कममा रहेका छन् । बिशेष गरि केराउका बिभिन्न जिनोटाइप (जातहरु) का उत्पादकत्व र उत्पादनशीलता बारेको तथ्यांक संकलन गर्ने उदेश्यले यो परीक्षण ईस्वी सम्वत २०१५ र २०१६ को हिउँदमा कषि अनुसन्धान केन्द्र, वागवानी फार्म, पाखीबास, धनकुटामा गरिएको थियो। प्रयोगहरु उपयुक्त डिजाईनमा एधार थरिका उपचार संयोजनलाई समावेश गरी तीन पटक दोहय्याईएको थियो। दुवै बर्ष अक्टोबर महिनाको पहिलो सातामा बीउ रोपिएको थियो । परीक्षणमा राखिएका जातहरुले केही बृद्वि मापनगर्ने गुणहरु, उत्पादकत्व तथा उत्पादनमुखी गुणहरुमा तथ्यांकीय रुपमा खास प्रभाव पारेको देखियो। परिक्षणबाट विभिन्न गुणहरु मध्ये हरियो कोसा उत्पादनकालागी अगौटे जातका रुपमा डी.जी.पी. -०४ को बाली कुल १०३ दिनमा तयार भयो भने, धेरै संख्यामा प्रतिबोट हरियो कोसा (१३.०) डी.जी.पी.०६ बाट उत्पादन भएको पाईयो। त्यसैगरी, प्रतिकोसा बीउको संख्या $\sqsubset$ गोटा सबै भन्दा धेरै डी.जी.पी.-०१ बाट भयो र डी.जी.पी.-०९ ले सबैभन्दा धैरै ताजा हरियो कोसा उत्पादन १६.१४ टन प्रति हेक्टर र आरकेलले १६.३२ टन प्रति हेक्टर दिएको थियो।

\section{INTRODUCTION}

Garden pea is an important winter legume food crop used as fresh green seeds or tender green pods (Ghale et al 2004). Green immature and dry peas are all season favorite food and are always in market demand. Additionally, the legume root enriches the soil fertility with nitrogenous compound and organic matters. The green peas are cultivated in many countries of the tropics and subtropics (Singh and Singh 1999, Shinde 2000, Javaid et al 2002, DoAFF 2011). In Nepal, green peas are sown in winter tarai area of plains, but in summer in hills (Ghale et al 2004; Poon et al 2004) indicating that extreme frost and hot temperatures should be avoided for better production. The garden peas thrive well in a relatively cool weather; and withstand relatively low temperatures especially during the seedling stage. The seeds can germinate at a minimum temperature of $5^{\circ} \mathrm{C}$ and the optimum temperature for germination is about $22^{\circ} \mathrm{C}$ (DoAFF 2011). Based on the seed performance, the pea varieties can be grouped into two distinct group viz. round or smooth seeded and wrinkled seeded.

Pea is one of the most important vegetable cash crops of Eastern mid-hills of Nepal. The crop covers the maximum area of 6982 ha with a production of $64883 \mathrm{t}$ and productivity of $9.3 \mathrm{t} / \mathrm{ha}$ of the country contributing around $6255 \mathrm{t}$ from the mid-hills area of the Eastern Nepal (ABPSD 2013/2014). Keeping in view the importance of the crop and the germplasm, the present 
study was conducted at Agricultural Research Station, Pakhribas to estimate the genetic variation in the available pea germplasm for economically important traits to select the elite genotypes for further utilization by the breeders.

\section{MATERIALS AND METHODS}

The main aim of the present experiments was to evaluate the performance of the various genotypes of garden pea. The treatments consisted of eleven genotypes of garden pea namely; DGP-01, DGP-02, DGP-03, DGP-04, DGP-05, DGP-06, DGP-07, DGP-08, DGP-09, DGP-10 and Arkel (Check). The experiments were conducted in two consecutive years from October to March of 2014-15 and 2015-16 in the Agricultural Research Station, Pakhribas. The experiment was conducted in the Randomized Complete Block Design with three replications. The spacing was maintained at $50 \mathrm{~cm}$ row to row and $10 \mathrm{~cm}$ plant to plant. Thus, the individual plot size was $3.6 \mathrm{~m}^{2}(2 \mathrm{~m} \mathrm{x} 1.8 \mathrm{~m})$ with the total of 72 plants population per plot. The plots were fertilized with Farm Yard Manure (FYM) @ 15 t/ha and Nitrogen: Phosphorus: Potassium (NPK) @ 30:40:40 kg/ha. Whole amount of compost, $\mathrm{P}, \mathrm{K}$ and half amount of $\mathrm{N}$ was applied as basal dose and remaining $\mathrm{N}$ was supplied as top dressing during the flowering stage. Irrigation was provided as and when necessary in all plots. The major observations on days to first fresh pod harvest, number of pods per plant, numbers of seeds per pod, length of pod and fresh pod yield were collected and analyzed. The data was analyzed by using Gen Stat software.

\section{RESULTS}

\section{Reproductive characteristics}

The position of the first flower node ranged from 7.0 (DGP-04) to 10.0 (DGP-03) followed by DGP-09 at 9.0 node (Table 1). Days to first flowering by the genotypes showed the significant $(\mathrm{P} \leq 0.05)$ difference in both the years. The days to flowering was early with Arkel and DGP-06 (40 DAS). Similarly, DGP-09 showed late flowering (59 DAS). Evaluated genotypes showed significantly $(\mathrm{P} \leq 0.05)$ different response to the days to harvesting of the green pods (Table 1$)$. The genotype DGP05 was early to green pod harvest (104 DAS) followed by DGP-07 (104 DAS) whereas, DGP-03 was harvested at 116 DAS.

Table 1. Reproductive characteristics of garden pea at eastern mid-hills in 2015 and 2016

\begin{tabular}{|c|c|c|c|c|c|c|c|c|c|}
\hline \multirow[t]{2}{*}{ Genotype } & \multicolumn{3}{|c|}{ Position of $1^{\text {st }}$ flower node } & \multicolumn{3}{|c|}{ Days of first flowering } & \multicolumn{3}{|c|}{ Days to first pod harvest } \\
\hline & 2015 & 2016 & Mean & 2015 & 2016 & Mean & 2015 & 2016 & Mean \\
\hline DGP-01 & 7.73 & 9.33 & 8.53 & 44.67 & 49.67 & 47.17 & 103.33 & 109.00 & 106.17 \\
\hline DGP-02 & 8.73 & 8.93 & 8.83 & 47.67 & 51.67 & 49.67 & 103.33 & 113.00 & 108.17 \\
\hline DGP-03 & 9.00 & 11.47 & 10.23 & 48.33 & 53.00 & 50.67 & 113.33 & 117.00 & 115.17 \\
\hline DGP-04 & 6.87 & 7.33 & 7.10 & 42.00 & 47.00 & 44.50 & 115.00 & 105.00 & 110.00 \\
\hline DGP-05 & 7.93 & 8.30 & 8.12 & 40.67 & 46.67 & 43.67 & 106.00 & 101.00 & 103.50 \\
\hline DGP-06 & 9.00 & 7.40 & 8.20 & 32.67 & 47.67 & 40.17 & 109.00 & 101.00 & 105.00 \\
\hline DGP-07 & 8.33 & 8.80 & 8.57 & 48.33 & 51.00 & 49.67 & 103.00 & 105.00 & 104.00 \\
\hline DGP-08 & 8.80 & 9.47 & 9.13 & 40.67 & 50.33 & 45.50 & 103.33 & 105.00 & 104.17 \\
\hline DGP-09 & 9.53 & 8.93 & 9.23 & 51.33 & 66.00 & 58.67 & 109.33 & 109.00 & 109.17 \\
\hline DGP-10 & 7.27 & 9.27 & 8.27 & 44.33 & 50.33 & 47.33 & 106.00 & 109.00 & 107.50 \\
\hline Arkel & 7.07 & 7.23 & 7.15 & 33.33 & 47.00 & 40.17 & 109.00 & 105.00 & 107.00 \\
\hline Mean & 8.21 & 8.77 & 8.49 & 43.09 & 50.94 & 47.02 & 107.33 & 107.20 & 107.26 \\
\hline F-test & NS & $* *$ & $* *$ & $* *$ & $* *$ & $* *$ & * & NS & $* *$ \\
\hline LSD & 1.97 & 1.61 & 1.37 & 5.77 & 7.36 & 4.7 & 7.53 & 11.53 & 4.3 \\
\hline $\mathrm{CV}, \%$ & 14.1 & 10.8 & 9.5 & 7.90 & 8.5 & 5.9 & 4.1 & 6.3 & $2 . .4$ \\
\hline
\end{tabular}

*, Significant at $P \leq 0.05 . * *, P \leq 0.01$. LSD, least significant difference. $C V$, coefficient of variance

\section{Pod characteristics}

The length of garden pod was observed significantly $(\mathrm{P} \leq 0.05)$ different among genotypes during year 2015 while, the result was non-significant $(\mathrm{P} \leq 0.05)$ during 2016 (Table 2). However, the aggregated mean showed that the longest green pod was obtained from the genotype DGP-03 $(9.68 \mathrm{~cm})$ followed by DGP-08, DGP-09 $(9.44 \mathrm{~cm})$ and $(9.40 \mathrm{~cm})$ respectively. The shortest green pod was obtained from Arkel $(7.91 \mathrm{~cm})$. The two year's aggregated pod yield/plant showed significant $(\mathrm{P} \leq$ 0.05) difference among the genotypes. The highest number of pods/plant was recorded in the genotype DGP-08 (13.33) followed by DGP-10 with (13.32) while, the lowest number of pods was harvested from DGP-04 (6.03). The effect of genotypes in the number of seeds/pod is non-significant, the highest number of seeds/pod were obtained from DGP-01 (7.51) and the lowest from Arkel (6.09) (Table 2). 
Table 2. Pod characteristics of garden pea at eastern mid hills during 2015 and 2016.

\begin{tabular}{|c|c|c|c|c|c|c|c|c|c|}
\hline \multirow{2}{*}{ Genotype } & \multicolumn{3}{|c|}{ Length of pod (cm) } & \multicolumn{3}{|c|}{ Number of pods/plant } & \multicolumn{3}{|c|}{ Number of seeds/pod } \\
\hline & 2015 & 2016 & Mean & 2015 & 2016 & Mean & 2015 & 2016 & Mean \\
\hline DGP-02 & 8.18 & 9.91 & 9.05 & 8.23 & 7.93 & 8.08 & 6.17 & 8.53 & 7.35 \\
\hline DGP-04 & 7.50 & 8.83 & 8.17 & 5.33 & 6.73 & 6.03 & 5.75 & 7.37 & 6.56 \\
\hline DGP-05 & 7.34 & 9.34 & 8.34 & 13.00 & 13.40 & 13.20 & 5.93 & 8.07 & 7.00 \\
\hline DGP-06 & 6.08 & 7.47 & 6.78 & 14.37 & 12.00 & 13.18 & 5.40 & 7.13 & 6.27 \\
\hline DGP-09 & 8.90 & 9.90 & 9.40 & 5.33 & 12.83 & 10.80 & 11.82 & 7.13 & 6.24 \\
\hline DGP-10 & 8.10 & 9.75 & 8.93 & 16.50 & 10.13 & 13.32 & 5.32 & 7.77 & 6.54 \\
\hline Arkel & 7.18 & 8.65 & 7.91 & 12.66 & 9.93 & 11.29 & 5.22 & 6.97 & 6.09 \\
\hline Mean & 8.09 & 9.32 & 8.70 & 11.82 & 9.88 & 10.85 & 5.75 & 7.60 & 6.68 \\
\hline F-test & $* *$ & NS & $* *$ & $*$ & NS & $*$ & NS & NS & NS \\
\hline LSD & 1.36 & 1.52 & 1.08 & 6.44 & 6.10 & 4.27 & 1.26 & 1.89 & 1.04 \\
\hline
\end{tabular}

*, significant at $P \leq 0.05$. **, $P \leq 0.01$. LSD, least significant difference. $C V$, coefficient of variance

\section{Pod yield characteristics}

The two year's average weight of 100 green seed was significantly $(\mathrm{P} \leq 0.05)$ different among the tested genotypes (Table 3). The maximum weight of 100 green seed $(51 \mathrm{~g})$ was from the genotypes DGP-09 and DGP-03 followed by DGP-04 (48.67g), while the minimum was from DGP-07 $(41.25 \mathrm{~g})$. The fresh pod yield showed non-significant $(\mathrm{P} \leq 0.05)$ difference among the genotypes in year 2014-15, while significant difference $(\mathrm{P} \leq 0.05)$ in year 2015-16 and average yield of both the years. The highest pod yield/hectare was observed with DGP-09 (18.14 t/ha) followed by Arkel (16.32 t/ha), while DGP-01 with (10.67 t/ha) showed the lowest pod yield (Table 3).

Table 3. Pod yield of garden pea at eastern mid-hills in 2015 and 2016

\begin{tabular}{|c|c|c|c|c|c|c|}
\hline Genotype & \multicolumn{3}{|c|}{100 green seed weight $(\mathrm{g})$} & \multicolumn{3}{|c|}{ Fresh pod yield (t/ha.) } \\
\hline DGP-02 & 39.30 & 43.33 & 41.33 & 10.00 & 17.73 & 13.87 \\
\hline DGP-04 & 47.30 & 50.00 & 48.67 & 8.89 & 13.27 & 11.08 \\
\hline DGP-05 & 44.00 & 42.50 & 43.25 & 10.46 & 21.48 & 15.97 \\
\hline DGP-06 & 39.00 & 46.83 & 42.92 & 9.07 & 20.51 & 14.79 \\
\hline DGP-09 & 53.30 & 48.67 & 51.00 & 16.34 & 19.94 & 18.14 \\
\hline DGP-10 & 40.00 & 46.50 & 43.25 & 9.21 & 18.38 & 13.80 \\
\hline Arkel & 50.00 & 47.00 & 48.50 & 12.87 & 19.77 & 16.32 \\
\hline Mean & 44.4 & 45.64 & 45.00 & 10.28 & 18.11 & 14.20 \\
\hline F-test & $*$ & NS & $*$ & NS & $*$ & $*$ \\
\hline LSD & 10.75 & 7.70 & 6.43 & 5.28 & 5.18 & 3.85 \\
\hline
\end{tabular}

*, significant at $P \leq 0.05 . * *, P \leq 0.01$. LSD, least significant difference. $C V$, coefficient of variance

\section{DISCUSSION}

The significant $(\mathrm{P} \leq 0.05)$ difference in all the measured growth and yield parameters was observed among the evaluated genotypes when data combined analysis for two years (Table 1, 2 and 3). Difference in the position of first flower node, days to first flowering and early to harvesting was recorded during the both consecutive growing years. The position of first flowering node ranged from 7.10 to $10.23 \mathrm{~cm}$ while comparing the both year's data. Similar to the findings of this study, Poon et al (2004) also showed similar results in position of first flower node and days to first flowering. 
From the two year's average, the longest green pod was obtained from the genotype DGP-03 $(9.68 \mathrm{~cm})$ followed by DGP-08 $(9.44 \mathrm{~cm})$ and the shortest from Arkel with $(7.91 \mathrm{~cm})$. Similar findings have been reported by Ghale et al (2004) in Malepatan, Pokhara, Kaski a mid-hill conditions and Choudhary and Sharma (2004). The average pod yield/plant showed significant $(\mathrm{P} \leq$ $0.05)$ difference among the genotypes. The highest number of pods/plant (13.33) was obtained from the genotype DGP-08 and the lowest from DGP-04 (6.03). Similarly, the number of seeds per pod was obtained highest from DGP-01 (7.51) and the lowest from Arkel with (6.09). Results of the present study are in agreement with those by Choudhary and Sharma (2004) and Singh and Singh (1999), who reported almost similar results in pods yield per plant among the tested varieties. The results showing that these tested genotypes were mostly tolerant to mid hills conditions, especially to many diseases and other pathogen.

Green seed yield and total fresh pod yield showed the significant $(\mathrm{P} \leq 0.05)$ difference among the assessed genotypes. The fresh pod yield showed non-significant difference among the genotypes during 2015 while, significant difference during 2016 and mean yield of both the years. The highest fresh pod yield per hectare was observed in DGP-09 (18.14 t/ha) followed by Arkel (16.32 t/ha) while, DGP-01 showed the lowest fresh pod yield with (10.67 t/ha). The findings of Javaid et al (2002), Chadha et al (2010) and Chadha et al (2013) support these findings. Shinde (2000) had also studied genetic variability among 73 pea cultivars with respect to different traits in India. The results probably indicated that the present genotypes had high range of tolerance to many agro-ecological condition showing almost same production and productivity in far off Indian and mid hill conditions of eastern Nepal. Also, indicating that the green pea genotypes can be successfully and commercially cultivated even in mid hill agro-ecological conditions. On the basis of two year's experiments in eastern mid hills condition of Pakhribas, garden pea genotype DGP-09 and Arkel are recommended for cultivation in the mid-hills region of eastern Nepal.

\section{REFERENCES}

ABPSD. 2014. Statistical information on Nepalese agriculture. Government of Nepal, Ministry of Agriculture and Cooperatives. AgriBusiness Promotion and Statistics Division, Singha Durbar, Kathmandu, Nepal.

Chadha S, A Sharma and YS Paul .2010. Performance of different pea genotypes under organic farming ecosystem. Himachal J. Agric. Res. 36)2:(241-242.

Chadha S, Rameshwar, JP Saini and S Sharma .2013. Performance of different varieties of pea (Pisum sativum L.) under organic farming conditions in mid himalayas. International J. Agric. Food Science Tech. 4)7:(733-738.

Choudhary DK and RR Sharma. 2004. Correlation and Path Analysis in F1 and F2 Generations of Garden Pea. In: Agricultural Research for Enhancing Livelihood of Nepalese People (BK Joshi, SL Joshi and KP Paudyal, eds). Proc. $2^{\text {nd }}$ SAS-N Convention, 30 July-1 Aug 2003, Kathmandu, pp.204-206.

DoAFF. 2011. Garden pea (Pisum sativum L.). Republic of South Africa. Department of Agriculture, Forestry and Fisheries.

Ghale MS, BH Adhikary, BJ BC and C Adhikary. 2004. Production Potential of Different Pea (Pisum sativum L.) Genotypes in Acid Soils of Malepatan. In: Agricultural Research for Enhancing Livelihood of Nepalese People (BK Joshi, SL Joshi and KP Paudyal, eds). Proc. $2^{\text {nd }}$ SAS-N Convention, 30 July-1 Aug 2003, Kathmandu, pp.249-251.

Javaid A, A Ghafoor and R Anwar. 2002. Evaluation of local and exotic pea (Pisum sativum L.) Germplasm for vegetable and dry grain traits. Pak. J. Bot. 34(4):419-427.

Poon TB, HN Regmi, BB Pokhrel, OB Oli and SR Sharma. 2004. Potential of Promising Varieties of Garden Pea in Relation to Determinate Characters, the Efficiency of Green Pod Yield and Monetary Returns under the Mid-hill Environments of Dailekh. In: Agricultural Research for Enhancing Livelihood of Nepalese People (BK Joshi, SL Joshi and KP Paudyal, eds). Proc. $2^{\text {nd }}$ SAS-N Convention, 30 July-1 Aug 2003, Kathmandu, pp.111-114.

Shinde KG .2000. Genetic parameters for some quantitative and qualitative traits in pea (Pisum sativum L.). Orrisa J. Hort. 28(1):21-24.

Singh V and SP Singh. 1999. Variability and correlation studies in pea. Annuals Agri. Biol. Res. 4(1):87-91. 